\title{
NF-Kappa-B Inhibitor Delta
}

National Cancer Institute

\section{Source}

National Cancer Institute. NF-Kappa-B Inhibitor Delta. NCI Thesaurus. Code C150062.

NF-kappa-B inhibitor delta (313 aa, $233 \mathrm{kDa}$ ) is encoded by the human NFKBID gene.

This protein may be involved in the regulation of nuclear factor-kappa-B signaling-

dependent cytokine gene expression. 